\title{
Chemical Speciation and Mobility of Some Heavy Metals in Soils around Automobile Waste Dumpsites in Northern Part of Niger Delta, South Central Nigeria
}

\author{
OSAKWE, S A \\ Department of Chemistry, Delta State University, Abraka \\ e-mail:saosakwe@yahoo.com
}

\begin{abstract}
The mobility of some heavy metals (Fe, $\mathrm{Co}, \mathrm{Ni}$ and $\mathrm{Mn}$ ) in soils around automobile waste dumpsites in Northern part of Niger Delta was assessed using Tessier et al. five syteps sequential chemical extraction procedure. The results showed that majority of iron and manganese were associated with the residual fraction with the average levels of $29.2 \%$ and $24.43 \%$ respectively. The exchangeable fraction was the most important fraction for cobalt with the average level of $39.53 \%$, while the organic fraction contained the predominant species of nickel with an average level of $22.97 \%$. For the total concentrations of the metals, iron ranging from $\left(\mathrm{mgkg}^{-1}\right) 768.30$ to 2897.00 was the highest followed by manganese ranging from 1.78 to 19.92 and then cobalt and nickel which ranged from 0.28 to 2.42 and 0.084 to 0.512 respectively. The mobility factors for the metals in all the sites ranged from 20.37 to 90.90 for cobalt, 15.83 to 62.07 for nickel, 25.50 to 60.43 for manganese and 16.49 to 32.13 for iron following the order $\mathrm{Co}>\mathrm{Ni}>\mathrm{Mn}>\mathrm{Fe}$. The relatively high mobility factors observed for cobalt in some sites coupled with its comparatively high concentration in the exchangeable fraction, indicates high mobility, lability and bioavailability for cobalt in the soils studied. The other metals (Fe, Ni and $\mathrm{Mn}$ ) which are strongly bound to soil matrix are not readily availably for introduction into the food chain. The results suggest that there is no serious contamination hazard with the metals studied, considering the geochemical phases in which Fe, Ni and Mn were associated with, and the low total metal concentration of Co, even with its relatively high mobility. @JASEM
\end{abstract}

The behaviour and fate of metals are governed by a range of different physicochemical processes which dictate their availability and mobility in the soil or sediment system. The knowledge of the chemical forms of soluble heavy metals or of heavy metals associated with particulates or colloids is essential for estimating the bioavailability, mobility and chemical reactivity in soils and sediments (Hickey and Kittrick, 1984). To assess the bioavailability of heavy metals, sequential extraction procedure consists of a series of chemical extractants, each being more drastic in action and of different nature than the previous one (Chaudhary and Banerjee, 2007).

Soil is relatively heterogeneous in terms of its physical chemical and biological characteristics, (Hakanson, 1992). Heavy metals are associated with various soil components in different ways and these associations determine their mobility and availability (Ahumuda et al., 1999).

In recent years there has been increased interest in the studies on speciation or chemical forms of heavy metals in polluted soils using sequential extraction techniques because these provide knowledge on metal affinity to soil components and the strength with which they are bound to matrix (Kotoky et al., 2003). The use of sequential extractions, although more time consuming, furnishes detailed information about the origin, mode of occurrence, biological and physicochemical availability, mobilization and transport of trace metals (Tessier et al., 1979). Among the numerous extraction schemes described in literature, the procedure of Tessier et al., (1979) is one of the most thoroughly researched and widely used procedures to evaluate the possible chemical association of metals in soils and sediments.

The soils around automobile waste dumpsites are considered to be contaminated by heavy metals since these waste dumpsites consist primarily of automobile and machine parts and scraps at various stages of corrosion, discarded motor batteries and tyres, cans, cables, etc.

The aim of the present study is to investigate the different chemical forms of $\mathrm{Fe}, \mathrm{Co}, \mathrm{Ni}$ and $\mathrm{Mn}$ in the soils around the automobile waste dumpsites and to assess the association and bioavailability of these metals and their environmental contamination risk between the different geochemical phases based on chemical speciation.

\section{MATERIALS AND METHODS}

The study Area: The study area located in the Northern part of the Niger Delta, South Central of Nigeria, lies within the coordinates of latitude $6^{0}, 05^{1} \mathrm{~N}$ to $6^{0} 16^{1} \mathrm{~N}$ and longitude $6^{0} 07^{1} \mathrm{E}$ to $6^{0} 12^{1} \mathrm{E}$. The undulating rugged sedimentary terrain with steep slopes marks the principal relief feature of the area. The mean annual rainfall in this area ranges between $2540-3500 \mathrm{~mm}$ and temperature varies between $28^{\circ} \mathrm{C}$ to $33^{\circ} \mathrm{C}$ around March and $23^{\circ} \mathrm{C}-30^{\circ} \mathrm{C}$ around August. The area experiences an average industrialization and commercial activities and large population of automobiles attracts many mechanic workshops and automobile dumpsites.

Sampling and Analysis: Soil samples were collected from selected automobile waste dumpsites at depths of $0-15 \mathrm{~cm}, 15-30 \mathrm{~cm}$, and $30-45 \mathrm{~cm}$, representing top soils, sub soils and bottom soils respectively. The soil samples were air-dried, homogenized by grinding, and filtered through a $2 \mathrm{~mm}$ mesh sieve. They were then oven-dried at $105 \pm 0.5^{\circ} \mathrm{C}$ to a constant mass, cooled and stored in labelled plastic cans until analysis (Allen et al., 1974). The samples for 
atomic absorption spectroscopic analysis were digested using a mixture of $2 \mathrm{ml} 60 \%$ perchloric acid, $15 \mathrm{ml}$ nitric acid, and $1 \mathrm{ml}$ sulphuric acid (Burrell 1974). For the chemical fractionation of the metals under study, the procedure of Tessier et al., (1979) was selected. In this method heavy metals, were separated into five operationally defined fractions:

Exchangeable $\left(\mathrm{F}_{1}\right)$, bound to carbonate $\left(\mathrm{F}_{2}\right)$, bound to Fe-Mn oxide $\left(\mathrm{F}_{3}\right)$, bound to organic matter $\left(\mathrm{F}_{4}\right)$, and residual fraction $\left(\mathrm{F}_{5}\right)$,

$1 \mathrm{~g}$ of the soil sample was weighed and extracted into five fractions as follows;

ii. $\mathbf{F}_{1}$ : Exchangeable: The soil sample was extracted at room temperature for 1 hour with $8 \mathrm{ml}$ of $1 \mathrm{M}$ magnesium chloride solution at $\mathrm{pH} 7.0$ with continuous agitation.

iii. $\mathbf{F}_{2}$ : Metals Bound to Carbonate: The residue from (i) was leached at room temperature with $8 \mathrm{ml}$ of $1 \mathrm{M}$ sodium acetate solution adjusted to $\mathrm{pH} 5.0$ with acetic acid. Continuous agitation was maintained.

iv. $\quad \mathbf{F}_{3}$ : Metals Bound to Fe-Mn Oxide: The residue from (ii) was extracted with $20 \mathrm{ml}$ of $0.04 \mathrm{M}$ hydroxylamine chloride $\left(\mathrm{NH}_{2} \mathrm{OH} . \mathrm{HCl}\right)$ in $25 \%(\mathrm{v} / \mathrm{v})$ acetic acid and was heated to $96^{\circ} \mathrm{C}$ with occasional agitation for 6 hours.

v. $\mathbf{F}_{4}$ : Metals Bound to Organic Matter: The residue from (iii) was extracted with $3 \mathrm{ml}$ of $0.02 \mathrm{M}$ nitric acid $\left(\mathrm{HNO}_{3}\right)$ and $5 \mathrm{ml}$ of $30 \%$ Hydrogen peroxide $\left(\mathrm{H}_{2} \mathrm{O}_{2}\right)$ adjusted to $\mathrm{pH} 2.0$ with nitric acid and the mixture was heated to $86^{\circ} \mathrm{C}$ for 3 hours with intermittent agitation. The mixture was cooled and $5 \mathrm{ml}$ of $3.2 \mathrm{M}$ ammonium acetate $\left(\mathrm{NH}_{4} \mathrm{OAc}\right)$ in $20 \%$ $(\mathrm{v} / \mathrm{v})$ nitric acid $\left(\mathrm{HNO}_{3}\right)$ was added and the sample was diluted to $20 \mathrm{ml}$ and agitated continuously for 30 minutes.

vi. $\mathbf{F}_{5}$ : Residual Metals: The residue from (iv) was digested with a mixture of Hydrofluoric acid, nitric acid and perchloric acid.

The supernatant from each extraction step was removed with a pipette and analyzed for total metal concentrations using acetylene flame Atomic Absorption Spectrophotometer (Perkin Elmer Model Analyst 2002), fitted with deuterium lamp for background correction, following the procedure of Sakata (1983). When continuous agitation was required, the samples were shaken lengthwise on a mechanical shaker at 265 oscillations per minute with a stroke of $8 \mathrm{~cm}$.

Heating of the samples was done using Al block heater. Standards for all metals were prepared for each extraction step in the same matrix as the extracting reagent to minimize matrix effects. Standard addition technique and background corrections using blanks were employed to overcome interferences. At least one duplicate and one spike sample was run for every two samples to verify the precision of the method. The spike recovery and the precision was found within $100 \pm 10 \%$.

Appropriate quality control measures and recovery study were carried out. All reagents used in this study were of pure analytical grade and were checked for possible trace metal contamination. All glasswares for metal analysis were previously soaked in $14 \%$ nitric acid $\left(\mathrm{HNO}_{3}\right)(\mathrm{v} / \mathrm{v})$, for 24 hours to remove all entrained metals, washed with detergents and rinsed with deionized water.

\section{RESULTS AND DISCUSSION}

Tables 1-4 present the concentrations of the metals in various geochemical fractions of the soil while the percentage metals in the fractions are presented in Table 5.

Table 1: Concentrations $\left(\mathrm{mgkg}^{-1}\right)$ of iron $(\mathrm{Fe})$ in various geochemical fractions of the soil $(\mathrm{F} 1=$ Exchangeable, Carbonate $=$ $\mathrm{F}_{2}$, ; non-manganese Oxide $=\mathrm{F}_{3}$; Organic matter $=\mathrm{F}_{4}$, Residual $=\mathrm{F}_{5}, \mathrm{SS}=$ sampling sites

\begin{tabular}{|c|c|c|c|c|c|c|}
\hline $\mathrm{SS}$ & $\mathrm{D}(\mathrm{cm})$ & $\mathrm{F}_{1}$ & $\mathrm{~F}_{2}$ & $\mathrm{~F}_{3}$ & $\mathrm{~F}_{4}$ & $\mathrm{~F}_{5}$ \\
\hline $\mathrm{A}$ & $0-15$ & 280.50 & 277.30 & 360.20 & 480.30 & 672.90 \\
& $15-30$ & 260.30 & 548.90 & 562.30 & 802.40 & 720.30 \\
& $30-45$ & 101.46 & 121.66 & 151.29 & 122.46 & 263.70 \\
\hline $\mathrm{B}$ & $0-15$ & 207.50 & 232.70 & 633.70 & 973.90 & 622.00 \\
& $15-30$ & 311.40 & 386.10 & 592.80 & 921.30 & 638.00 \\
& $30-45$ & 241.30 & 208.90 & 541.30 & 806.30 & 538.20 \\
\hline $\mathrm{C}$ & $0-15$ & 186.30 & 200.30 & 248.40 & 742.90 & 554.90 \\
& $15-30$ & 155.90 & 231.60 & 255.60 & 682.30 & 603.70 \\
& $30-45$ & 232.30 & 281.60 & 242.30 & 637.20 & 531.60 \\
\hline $\mathrm{D}$ & $0-15$ & 286.30 & 336.00 & 284.00 & 714.00 & 639.20 \\
& $15-30$ & 312.40 & 302.00 & 329.00 & 622.00 & 543.90 \\
& $30-45$ & 211.40 & 228.00 & 240.00 & 623.70 & 581.20 \\
\hline $\mathrm{E}$ & $0-15$ & 364.20 & 433.20 & 596.30 & 488.70 & 599.30 \\
& $15-30$ & 392.30 & 320.30 & 629.40 & 733.90 & 484.70 \\
& $30-45$ & 128.10 & 173.60 & 386.30 & 391.60 & 488.00 \\
\hline $\mathrm{F}$ & $0-15$ & 106.10 & 90.30 & 118.30 & 200.50 & 392.50 \\
& $15-30$ & 74.20 & 68.30 & 150.60 & 198.40 & 282.70 \\
& $30-45$ & 92.30 & 83.70 & 120.60 & 151.70 & 233.70 \\
\hline
\end{tabular}


Table 2: Concentrations $\left(\mathrm{mgkg}^{-1}\right)$ of cobalt $(\mathrm{Co})$ in various geochemical fractions of the soil

\begin{tabular}{|l|l|l|l|l|l|l|}
\hline SS & $\begin{array}{l}\mathrm{D} \\
(\mathrm{cm})\end{array}$ & $\mathrm{F}_{1}$ & $\mathrm{~F}_{2}$ & $\mathrm{~F}_{3}$ & $\mathrm{~F}_{4}$ & $\mathrm{~F}_{5}$ \\
\hline $\mathrm{A}$ & $0-15$ & 0.02 & 0.00 & 0.00 & 0.03 & 0.02 \\
& $15-30$ & 0.01 & 0.00 & 0.004 & 0.004 & 0.004 \\
& $30-45$ & 0.01 & 0.001 & 0.001 & 0.002 & 0.04 \\
\hline $\mathrm{B}$ & $0-15$ & 0.01 & 0.00 & 0.00 & 0.00 & 0.001 \\
& $15-30$ & 0.02 & 0.00 & 0.004 & 0.004 & 0.03 \\
& $30-45$ & 0.03 & 0.00 & 0.01 & 0.002 & 0.002 \\
\hline $\mathrm{C}$ & $0-15$ & 0.00 & 0.00 & 0.04 & 0.00 & 0.005 \\
& $15-30$ & 0.03 & 0.04 & 0.005 & 0.02 & 0.00 \\
& $30-45$ & 0.02 & 0.00 & 0.01 & 0.00 & 0.003 \\
\hline $\mathrm{D}$ & $0-15$ & 0.05 & 0.003 & 0.002 & 0.005 & 0.04 \\
& $15-30$ & 0.03 & 0.001 & 0.004 & 0.004 & 0.06 \\
& $30-45$ & 0.03 & 0.001 & 0.006 & 0.006 & 0.006 \\
\hline E & $0-15$ & 0.46 & 0.41 & 0.63 & 0.17 & 0.67 \\
& $15-30$ & 0.23 & 0.33 & 0.46 & 0.42 & 0.56 \\
& $30-45$ & 0.17 & 0.39 & 0.06 & 0.29 & 0.17 \\
\hline
\end{tabular}

The majority of iron in the soils was associated with the residual fraction, having the range from $22.89 \%$ to $36.76 \%$ with an average of $29.2 \%$. This is consistent with the results of Horsfall and Spiff, (2005); Gupta and Chen, (1975); Ramos et al., (1994); Abeh et al., (2007); Segarra et al., (2008). The residual fraction is considered the most stable, less reactive and less bioavailable since it is occluded within the crystal lattice layer of silicates and well crystallized oxide minerals (Abeh et al., 2007; Schawarzenbach et al., 1993). The fraction can be taken as a guide to the degree of pollution of the soil. The smaller the percentages of the metal present in this fraction, the greater the pollution of the area (Horsfall and Spiff, 2005). The high percentage of iron found in residual fraction is an important repository of iron in the soil. In sandy soil that contains little clay, iron oxide could be leached through the soil and impact ground water quality.

Organic fraction with iron content varied from $23.93 \%$ to $35.64 \%$ and an average of $28.45 \%$, had next high average percentage of iron. High iron content $(28.28 \%)$ in organic fraction has been reported (Urunmatsoma and Ikhuoria, 2005). Organic compounds of heavy metals can be directly or indirectly introduced into soil through the formation of complexes and can be taken up by plants. Organic content is associated with the production of gas, and in sandy soil that contains little clay, organic matter and phosphate can leach through the soil and impact ground water (Urunmatsoma and Ikhuoria, 2005).

Next in importance for iron content was Fe-Mn oxide fraction having the range between $12.90 \%$ and $24.76 \%$ with an average of $18.52 \%$. This fraction could be considered relatively stable, slowly mobile and poorly available but could change with variations in redox conditions. It may become more soluble under reducing conditions and less so under oxidizing ones (Horsfall and Spiff, 2005). The considerable level of iron in Fe-Mn oxide fraction can be explained by the precipitation effect of Fe-Mn oxyhydroxides in water. Under strong oxidizing conditions and neutral $\mathrm{pH}$ value, $\mathrm{Fe}^{2+}$ can be transformed into $\mathrm{Fe}^{3+}$ rapidly precipitated as $\mathrm{Fe}$ oxyhydroxide (Stumm and Morgan, 1981).

The concentrations of iron found in carbonate fraction varied from $10.53 \%$ to $19.95 \%$ with an average of $13.57 \%$. The iron concentration reported here is in agreement with the result obtained by Abeh et al., (2007). Low iron content in this fraction has been reported (Horsfall and Spiff, 2005; Urunmatsoma and Ikhuoria, 2005; Zhang et al., 1998). The exchangeable fraction of iron ranged between $9.68 \%$ and $13.18 \%$ with an average of $11.61 \%$. Low iron in exchangeable fraction has been reported (Horsfall and Spiff, 2005). The carbonate and exchangeable fractions are released into solutions of low $\mathrm{pH}$, which can be related to stomach conditions (Evans et al.,1992). The association pattern of iron in the different phases were in the order residual $>$ organic $>\mathrm{Fe}-\mathrm{Mn}$ oxide $>$ carbonate $>$ exchangeable.

Table 4: Concentrations $\left(\mathrm{mgkg}^{-1}\right)$ of manganese in geochemical fractions of the soil

\begin{tabular}{|l|l|l|l|l|l|l|}
\hline $\mathrm{S}$ & $\begin{array}{l}\mathrm{D} \\
\mathrm{S}\end{array}$ & $\mathrm{F}_{1}$ & $\mathrm{~F}_{2}$ & $\mathrm{~F}_{3}$ & $\mathrm{~F}_{4}$ & $\mathrm{~F}_{5}$ \\
\hline $\mathrm{A}$ & $0-15$ & 2.63 & 3.16 & 3.28 & 3.11 & 3.28 \\
& $15-30$ & 2.43 & 2.67 & 2.24 & 2.33 & 2.94 \\
& $30-45$ & 1.28 & 1.44 & 1.48 & 2.06 & 2.37 \\
\hline $\mathrm{B}$ & $0-15$ & 2.92 & 2.45 & 3.21 & 4.26 & 5.62 \\
& $15-30$ & 1.28 & 3.06 & 2.98 & 3.48 & 6.22 \\
& $30-45$ & 1.98 & 1.66 & 2.31 & 1.74 & 3.42 \\
\hline $\mathrm{C}$ & $0-15$ & 1.96 & 1.19 & 4.31 & 1.16 & 1.16 \\
& $15-30$ & 1.93 & 1.94 & 2.67 & 2.01 & 2.05 \\
& $30-45$ & 1.25 & 1.63 & 2.51 & 1.22 & 2.82 \\
\hline $\mathrm{D}$ & $0-15$ & 3.16 & 3.21 & 3.46 & 5.44 & 4.26 \\
& $15-30$ & 3.14 & 3.06 & 3.28 & 3.71 & 4.08 \\
& $30-45$ & 2.63 & 2.84 & 2.97 & 3.82 & 5.19 \\
\hline $\mathrm{E}$ & $0-15$ & 3.54 & 8.48 & 3.01 & 1.15 & 2.63 \\
& $15-30$ & 1.85 & 2.99 & 1.97 & 3.67 & 1.18 \\
& $30-45$ & 1.81 & 1.58 & 1.47 & 2.33 & 1.15 \\
\hline $\mathrm{F}$ & $0-15$ & 0.44 & 0.84 & 0.56 & 0.58 & 1.42 \\
& $15-30$ & 0.29 & 0.33 & 0.12 & 0.09 & 0.96 \\
& $30-45$ & 0.37 & 0.53 & 0.42 & 0.44 & 0.92 \\
\hline
\end{tabular}


The exchangeable fraction was the most important fraction for cobalt having the range of $14.43 \%$ to 68.97 with an average of $39.53 \%$. This fraction represents heavy metals soluble in water as well as those held by electrostatic adsorption. The amount of metal in this phase indicated the environmental conditions of the soil. The high percentage of cobalt in this fraction suggests a greater contamination risk for cobalt.

Next in importance for cobalt content was the residual fraction having the range from $4.62 \%$ to $43.84 \%$ and an average of $27.00 \%$. Fe $-\mathrm{Mn}$ oxide fraction contained cobalt in the range of $3.42 \%$ and 31.79 with an average of $14.19 \%$. This was followed by organic bound fraction with the range between $5.31 \%$ and $24.66 \%$ and an average of $11.86 \%$. Carbonate fraction was of the least importance with range between $0.00 \%$ and $23.12 \%$ with an average of $7.46 \%$. Cobalt was not available in this fraction in sites $\mathrm{B}$ and $\mathrm{F}$.

Nickel was predominantly associated with organic and residual fractions averaging $22.97 \%$ and $22.24 \%$ respectively. Organic nickel varied from $13.63 \%$ to $35.21 \%$ while residual nickel varied from $10.12 \%$ to $34.38 \%$. This predominance of inactive forms of nickel is consistent with other reports of contaminated soils (Gupta and Chen, 1975; Tessier and Campbell, 1980; Ma and Rao, 1997; Iwegbue, 2007; Abeh et al., 2007), although high levels of soluble nickel were found in Kaolin soil (Reedy et al., 2001). Tessier et al., 1979; Hickey and Kittrick 1984; Ryan et al. 2002; Kotoky et al. 2003; Horsfall and Spiff 2005; Egila and Nomyel (2002). Segarra et al.,(2008) reported high levels of nickel in residual fraction. Norrish (1975) reported that nickel is commonly occluded by silicate during soil weathering. Nickel in Fe-Mn oxide fraction varied from $10.36 \%$ to $32.35 \%$ with an average of $19.67 \%$. Hickey and Kittrick (1984) similarly reported significant amount of nickel in this fraction. Jenne (1968) had suggested that the levels of nickel in this fraction depend on how much Mn oxide is adsorbed in a given soil sample because $\mathrm{Ni}^{2+}$ could substitute for surface manganese in mixed valence Mn oxides. Exchangeable nickel varied from $7.52 \%$ to $50.17 \%$ with an average of $18.67 \%$ while carbonate fraction nickel varied from $10.12 \%$ to $27.84 \%$ with an average of $16.44 \%$. Similar levels of nickel in carbonate fraction were reported by Horsfall and Spiff, (2005). Residual fraction contained the predominant species of manganese. The levels varied from $14.96 \%$ to $39.71 \%$ with an average of $24.43 \%$. Relatively high level of manganese in residual fraction has been reported (Iwegbue, 2007; Horsfall and Spiff, 2005). The association of manganese with residual fraction implies partitioning into trioctahedral clay and/or crystalline oxides (Ryan et al.,2002). $\mathrm{Mn}^{3+}$ and $\mathrm{Mn}^{4+}$ are insoluble ions which form oxides such as $\mathrm{MnO}_{2}, \mathrm{MnOOH}$ and $\mathrm{Mn}_{3} \mathrm{O}_{4}$ or become incorporated into silicates (McBride, 1997).

The carbonate fraction forms the second most important species of manganese in the soil matrix. The levels of manganese in this fraction varied from $15.26 \%$ to $32.76 \%$ with an average of $20.21 \%$. Similar results were reported by Horsfall and Spiff, (2005) who observed an average manganese level of $19.07 \%$ in sediments of Diobu River in Port Harcourt. Iwegbue, (2007) reported an average of $22.6 \%$ manganese in carbonate fraction, in Ase River sediments in Niger Delta. These results corroborated observation of Pizzaro et al., 2003) who reported 13$25 \%$ of total manganese with carbonate fraction for Rapel reservoir (Chile) sediment. Abeh et al., (2007) reported an average of $20.33 \%$ carbonate manganese in street dust in Jos, Plateau State of Nigeria.

The percentage of total manganese in the Fe-Mn oxide fraction ranged from $13.24 \%$ of $31.77 \%$ with an average of $19.38 \%$. Abeh et al., (2007), reported manganese level in the range of $19.95 \%$ and $34.10 \%$ with an average of $24.72 \%$ while Iwegbue, 2007 reported the range from $13.38 \%$ to $55.06 \%$ of manganese in this fraction. The association of manganese may be attributed to its interference in the crystal of $\mathrm{Fe}$ oxide precipitate leading to its less occlusion (Abeh et al., 2007). Though, this fraction may be considered relatively stable, it becomes more soluble under acidic conditions and less so under oxidizing conditions (Carot et al. 2002; Graham and Stangoulis, 2003).

Organic fraction contained manganese in the range from 13.36 to $23.91 \%$ with an average of $19.38 \%$. Similar results were reported by Horsfall and Spiff, 2005, and Abeh et al.,(2007).

The exchangeable fraction of manganese ranged from $13.15 \%$ to $18.07 \%$ with an average of $15.56 \%$. Similar association of manganese with exchangeable fraction has been reported (Pizzaro et al.,2003; Iwegbue, 2007; Abeh et al.,2007). The relative percentage ranges in exchangeable and carbonate fractions suggest that manganese is (1) available on the exchange sites (2) possibly also present in the soluble carbonates such as cholomites which may occur in trace amounts and dissolve during the HOAc extraction (Iwegbue 2007). The $\mathrm{Mn}^{2+}$ ion is very soluble in water at $\mathrm{pH}$ less than 7 (Brooklin 1988; McBride, 1997) and given the $\mathrm{pH}$ range of these soils (4.9-7.4), soluble exchangeable $\mathrm{Mn}^{2+}$ is likely.

The accuracy of the sequential extraction procedure was evaluated by comparing for the samples, the total metal content with the sum of the metal fractions extracted in the five fractions (Table 6). The values are in close agreement showing some degree of accuracy in the sequential procedure used. 
TABLE 5: Percentage Metals in Various Geochemical Fractions of the Soil

\begin{tabular}{|c|c|c|c|c|c|c|c|}
\hline Sites & $\bar{A}$ & B & $\mathrm{C}$ & $\mathrm{D}$ & $\mathrm{E}$ & $\mathrm{F}$ & \\
\hline Metal Fractions & & & & & & & AVERAGE \\
\hline $\begin{array}{ll}\mathrm{Fe} & \\
\mathrm{F}_{1} & \text { Exchangeable } \\
\mathrm{F}_{2} & \text { Carbonate } \\
\mathrm{F}_{3} & \text { Fe-Mn oxide } \\
\mathrm{F}_{4} & \text { Organic } \\
\mathrm{F}_{5} & \text { Residual }\end{array}$ & $\begin{array}{l}13.18 \\
19.95 \\
22.36 \\
30.58 \\
33.98\end{array}$ & $\begin{array}{l}9.68 \\
10.54 \\
22.50 \\
34.39 \\
22.89\end{array}$ & $\begin{array}{l}9.93 \\
12.33 \\
12.90 \\
35.64 \\
29.21\end{array}$ & $\begin{array}{l}12.96 \\
13.85 \\
13.64 \\
31.34 \\
28.21\end{array}$ & $\begin{array}{l}12.05 \\
14.24 \\
24.76 \\
24.80 \\
24.15\end{array}$ & $\begin{array}{l}11.85 \\
10.53 \\
16.93 \\
23.93 \\
36.76\end{array}$ & $\begin{array}{l}11.61 \\
13.57 \\
18.52 \\
28.45 \\
29.20\end{array}$ \\
\hline $\begin{array}{l}\text { Co } \\
\mathrm{F}_{1} \text { Exchangeable } \\
\mathrm{F}_{2} \text { Carbonate } \\
\mathrm{F}_{3} \text { Fe-Mn oxide } \\
\mathrm{F}_{4} \text { Organic } \\
\mathrm{F}_{5} \text { Residual }\end{array}$ & $\begin{array}{l}27.40 \\
0.68 \\
3.42 \\
24.66 \\
43.84\end{array}$ & $\begin{array}{l}53.10 \\
0.00 \\
12.39 \\
5.31 \\
29.20\end{array}$ & $\begin{array}{l}28.90 \\
23.12 \\
31.79 \\
11.56 \\
4.62\end{array}$ & $\begin{array}{l}44.35 \\
2.02 \\
4.84 \\
6.05 \\
42.74\end{array}$ & $\begin{array}{l}14.43 \\
18.96 \\
28.36 \\
14.7 \\
23.49\end{array}$ & $\begin{array}{l}68.97 \\
0.00 \\
4.31 \\
8.62 \\
18.10\end{array}$ & $\begin{array}{l}39.53 \\
7.46 \\
14.19 \\
11.86 \\
27.00\end{array}$ \\
\hline $\begin{array}{ll}\mathrm{Ni} & \\
\mathrm{F}_{1} & \text { Exchangeable } \\
\mathrm{F}_{2} & \text { Carbonate } \\
\mathrm{F}_{3} & \text { Fe-Mn oxide } \\
\mathrm{F}_{4} & \text { Organic } \\
\mathrm{F}_{5} & \text { Residual }\end{array}$ & $\begin{array}{l}14.71 \\
14.71 \\
32.35 \\
20.59 \\
17.65\end{array}$ & $\begin{array}{l}11.95 \\
13.94 \\
10.36 \\
29.88 \\
33.86\end{array}$ & $\begin{array}{l}18.78 \\
18.54 \\
15.73 \\
35.21 \\
11.74\end{array}$ & $\begin{array}{l}50.17 \\
10.12 \\
12.73 \\
16.86 \\
10.12\end{array}$ & $\begin{array}{l}8.88 \\
13.49 \\
29.61 \\
13.65 \\
34.38\end{array}$ & $\begin{array}{l}7.52 \\
27.84 \\
17.76 \\
21.67 \\
25.71\end{array}$ & $\begin{array}{l}18.67 \\
16.44 \\
19.67 \\
22.97 \\
22.24\end{array}$ \\
\hline \begin{tabular}{ll} 
& \multicolumn{2}{l}{$\mathrm{Mn}$} \\
$\mathrm{F}_{1}$ & Exchangeable \\
$\mathrm{F}_{2}$ & Carbonate \\
$\mathrm{F}_{3}$ & Fe-Mn oxide \\
$\mathrm{F}_{4}$ & Organic \\
$\mathrm{F}_{5}$ & Residual
\end{tabular} & $\begin{array}{l}17.28 \\
19.82 \\
19.05 \\
20.45 \\
23.42\end{array}$ & $\begin{array}{l}13.15 \\
15.26 \\
18.09 \\
21.03 \\
32.47\end{array}$ & $\begin{array}{l}15.17 \\
16.64 \\
31.77 \\
15.34 \\
21.08\end{array}$ & $\begin{array}{l}16.46 \\
16.79 \\
17.90 \\
23.91 \\
24.94\end{array}$ & $\begin{array}{l}18.07 \\
32.76 \\
16.26 \\
17.95 \\
14.96\end{array}$ & $\begin{array}{l}13.24 \\
20.46 \\
13.24 \\
13.36 \\
39.71\end{array}$ & $\begin{array}{l}15.56 \\
20.21 \\
19.38 \\
19.38 \\
24.43\end{array}$ \\
\hline
\end{tabular}

Table 3: Concentrations $\left(\mathrm{mgkg}^{-1}\right)$ of Nickel in geochemical fractions of the soil

\begin{tabular}{|c|c|c|c|c|c|c|}
\hline SITES & Depth $(\mathrm{cm})$ & $\mathrm{F}_{1}$ & $\mathrm{~F}_{2}$ & $\mathrm{~F}_{3}$ & $\mathrm{~F}_{4}$ & $\mathrm{~F}_{5}$ \\
\hline $\mathrm{A}$ & $\begin{array}{l}0-15 \\
15-30 \\
30-45\end{array}$ & $\begin{array}{l}0.02 \\
0.02 \\
0.01\end{array}$ & $\begin{array}{l}0.03 \\
0.01 \\
0.01\end{array}$ & $\begin{array}{l}0.06 \\
0.04 \\
0.01\end{array}$ & $\begin{array}{l}0.03 \\
0.03 \\
0.01\end{array}$ & $\begin{array}{l}0.00 \\
0.02 \\
0.04\end{array}$ \\
\hline $\mathrm{B}$ & $\begin{array}{l}0-15 \\
15-30 \\
30-45\end{array}$ & $\begin{array}{l}0.02 \\
0.03 \\
0.01 \\
\end{array}$ & $\begin{array}{l}0.02 \\
0.02 \\
0.03 \\
\end{array}$ & $\begin{array}{l}0.02 \\
0.012 \\
0.02 \\
\end{array}$ & $\begin{array}{l}0.08 \\
0.02 \\
0.05 \\
\end{array}$ & $\begin{array}{l}0.05 \\
0.04 \\
0.08\end{array}$ \\
\hline $\mathrm{C}$ & $\begin{array}{l}0-15 \\
15-30 \\
30-45 \\
\end{array}$ & $\begin{array}{l}0.01 \\
0.05 \\
0.02 \\
\end{array}$ & $\begin{array}{l}0.03 \\
0.04 \\
0.009 \\
\end{array}$ & $\begin{array}{l}0.012 \\
0.015 \\
0.05\end{array}$ & $\begin{array}{l}0.09 \\
0.03 \\
0.03\end{array}$ & $\begin{array}{l}0.01 \\
0.01 \\
0.03\end{array}$ \\
\hline $\mathrm{D}$ & $\begin{array}{l}0-15 \\
15-30 \\
30-45 \\
\end{array}$ & $\begin{array}{l}0.52 \\
0.034 \\
0.041 \\
\end{array}$ & $\begin{array}{l}0.03 \\
0.06 \\
0.03 \\
\end{array}$ & $\begin{array}{l}0.031 \\
0.04 \\
0.08 \\
\end{array}$ & $\begin{array}{l}0.08 \\
0.08 \\
0.04 \\
\end{array}$ & $\begin{array}{l}0.02 \\
0.04 \\
0.06 \\
\end{array}$ \\
\hline $\mathrm{E}$ & $\begin{array}{l}0-15 \\
15-30 \\
30-45 \\
\end{array}$ & $\begin{array}{l}0.022 \\
0.018 \\
0.014 \\
\end{array}$ & $\begin{array}{l}0.031 \\
0.022 \\
0.029 \\
\end{array}$ & $\begin{array}{l}0.066 \\
0.063 \\
0.051 \\
\end{array}$ & $\begin{array}{l}0.024 \\
0.041 \\
0.018 \\
\end{array}$ & $\begin{array}{l}0.073 \\
0.096 \\
0.04\end{array}$ \\
\hline $\mathrm{F}$ & $\begin{array}{l}0-15 \\
15-30 \\
30-45 \\
\end{array}$ & $\begin{array}{l}0.066 \\
0.038 \\
0.041 \\
\end{array}$ & $\begin{array}{l}0.049 \\
0.022 \\
0.025\end{array}$ & $\begin{array}{l}0.144 \\
0.097 \\
0.092\end{array}$ & $\begin{array}{l}0.38 \\
0.016 \\
0.022\end{array}$ & $\begin{array}{l}0.231 \\
0.149 \\
0.166 \\
\end{array}$ \\
\hline
\end{tabular}

Mobility Factors of the Metals in the Soil Profile

The operationally defined extraction sequence fractionates the heavy metals in the soil in order of decreasing solubility. As a result, the exchangeable and carbonate $\left(\mathrm{F}_{1}+\mathrm{F}_{2}\right)$ fractions which are the early fractions, capture the most reactive and presumably the most mobile and bioavailable fractions (Kersten and Forstner, 1989).
The relative index of metal mobility was calculated as a mobility factor (MF) (Salbu et al, 1998; Narwal et al, 1999; Kabala and Singh, 2001) on the basis of the following equation.

$$
M F=\frac{F_{1}+F_{2}}{F_{1}+F_{2}+F_{3}+F_{4}+F_{5}} X 100
$$

Where $\mathrm{F}_{1}=$ Exchangeable metal content fraction $\mathrm{F}_{2}=$ Metal content bound to carbonate fractions 
$\mathrm{F}_{3}=$ Metal content bound to Fe-Mn oxide fraction

$\mathrm{F}_{4}=$ Metals content bound to organic matter fraction

$\mathrm{F}_{5}=$ Residual metal content fraction

A high MF value for heavy metals in soil has been interpreted as evidence of relatively high lability and biological availability (Karczewska 1996; Ma and Rao 1997; Ahumuda et al. 1999; Narwal et al. 1999; Kabala and Singh 2001).

The mobility factors (MF) of the metals for all the sites and soil depths are presented on Table 7

Fig. 6. Total concentrations of $\mathrm{Fe}, \mathrm{Co}, \mathrm{Ni}$ and $\mathrm{Mn}$ and the sum of fractions obtained by sequential extraction procedures

\begin{tabular}{|c|c|c|c|c|c|c|c|c|c|}
\hline \multicolumn{6}{|c|}{ Metal Total Concentrations $\left(\mathrm{mgkg}^{1}\right)$} & \multicolumn{4}{|c|}{ Sum of the Fractions $F_{1}$ to $F_{5}\left(\mathrm{mgkg}^{-1}\right)$} \\
\hline Sites & $\begin{array}{c}\text { Soil } \\
\text { Depth } \\
(\mathrm{cm})\end{array}$ & $\mathrm{Fe}$ & $\mathrm{Co}$ & $\mathrm{Ni}$ & $\mathrm{Mn}$ & $\mathrm{Fe}$ & $\mathrm{Co}$ & $\mathrm{Ni}$ & $\mathrm{Mn}$ \\
\hline $\mathrm{A}$ & $\begin{array}{c}0-15 \\
15-30 \\
30-45\end{array}$ & $\begin{array}{c}2111.6 \\
2897.00 \\
768.30\end{array}$ & $\begin{array}{l}0.073 \\
0.028 \\
0.060\end{array}$ & $\begin{array}{c}0.16 \\
0.13 \\
0.084\end{array}$ & $\begin{array}{c}12.71 \\
8.67 \\
12.30\end{array}$ & $\begin{array}{c}2071.2 \\
2894.2 \\
760.0\end{array}$ & $\begin{array}{c}0.70 \\
0.022 \\
0.054\end{array}$ & $\begin{array}{l}0.14 \\
0.12 \\
0.08\end{array}$ & $\begin{array}{c}15.46 \\
12.61 \\
8.61\end{array}$ \\
\hline B & $\begin{array}{c}0-15 \\
15-30 \\
30-45\end{array}$ & $\begin{array}{c}2670.0 \\
2852.00 \\
2341.00\end{array}$ & $\begin{array}{l}0.150 \\
0.038 \\
0.047\end{array}$ & $\begin{array}{l}0.195 \\
0.129 \\
0.211\end{array}$ & $\begin{array}{l}18.67 \\
17.16 \\
11.54\end{array}$ & $\begin{array}{l}2669.8 \\
2849.6 \\
2336.0\end{array}$ & $\begin{array}{l}0.011 \\
0.058 \\
0.044\end{array}$ & $\begin{array}{l}0.14 \\
0.12 \\
0.08\end{array}$ & $\begin{array}{c}15.46 \\
12.61 \\
8.61\end{array}$ \\
\hline $\mathrm{C}$ & $\begin{array}{c}0-15 \\
15-30 \\
30-45\end{array}$ & $\begin{array}{l}1938.0 \\
1931.0 \\
1933.0\end{array}$ & $\begin{array}{l}0.048 \\
0.099 \\
0.036\end{array}$ & $\begin{array}{l}0.128 \\
0.147 \\
0.131\end{array}$ & $\begin{array}{c}9.77 \\
10.26 \\
9.47\end{array}$ & $\begin{array}{l}1932.8 \\
1929.1 \\
1925.0\end{array}$ & $\begin{array}{l}0.045 \\
0.095 \\
0.033\end{array}$ & $\begin{array}{l}0.152 \\
0.145 \\
0.129\end{array}$ & $\begin{array}{c}8.98 \\
10.20 \\
9.43\end{array}$ \\
\hline $\mathrm{D}$ & $\begin{array}{c}0-15 \\
15-30 \\
30-45 \\
\end{array}$ & $\begin{array}{l}2262.0 \\
2118.0 \\
1888.0 \\
\end{array}$ & $\begin{array}{l}0.022 \\
0.101 \\
0.051\end{array}$ & $\begin{array}{l}0.219 \\
0.258 \\
0.257\end{array}$ & $\begin{array}{l}19.59 \\
17.31 \\
17.48\end{array}$ & $\begin{array}{l}2259.5 \\
2109.3 \\
1883.4\end{array}$ & $\begin{array}{c}0.01 \\
0.099 \\
0.049\end{array}$ & $\begin{array}{l}0.681 \\
0.254 \\
0.251\end{array}$ & $\begin{array}{l}19.53 \\
17.27 \\
17.45\end{array}$ \\
\hline $\mathrm{E}$ & $\begin{array}{c}0-15 \\
15-30 \\
30-45\end{array}$ & $\begin{array}{l}2486.0 \\
2465.0 \\
1577.0\end{array}$ & $\begin{array}{l}2.42 \\
2.16 \\
1.65\end{array}$ & $\begin{array}{l}0.231 \\
0.254 \\
0.155\end{array}$ & $\begin{array}{c}19.92 \\
11.69 \\
8.31\end{array}$ & $\begin{array}{l}2481.7 \\
2460.6 \\
1567.6\end{array}$ & $\begin{array}{l}2.34 \\
2.00 \\
1.62\end{array}$ & $\begin{array}{l}0.216 \\
0.240 \\
0.152\end{array}$ & $\begin{array}{c}19.89 \\
11.66 \\
8.29\end{array}$ \\
\hline$F$ & $\begin{array}{c}0-15 \\
15-30 \\
30-45\end{array}$ & $\begin{array}{l}1849.0 \\
1776.0 \\
1687.0\end{array}$ & $\begin{array}{l}0.058 \\
0.036 \\
0.050\end{array}$ & $\begin{array}{l}0.512 \\
0.338 \\
0.296\end{array}$ & $\begin{array}{l}3.87 \\
1.78 \\
2.69\end{array}$ & $\begin{array}{l}1844.7 \\
1774.2 \\
1682.0\end{array}$ & $\begin{array}{l}0.054 \\
0.032 \\
0.030\end{array}$ & $\begin{array}{l}1.311 \\
0.322 \\
0.296\end{array}$ & $\begin{array}{l}3.84 \\
1.79 \\
2.68\end{array}$ \\
\hline
\end{tabular}

Table 7: Mobility factors of the metals in the samples

\begin{tabular}{|l|l|l|l|l|l|}
\hline SITES & Soil Depth $(\mathrm{cm})$ & Fe & Co & Ni & Mn \\
\hline A & $0-15$ & 26.93 & 28.57 & 35.71 & 37.45 \\
& $15-30$ & 27.96 & 45.45 & 25.00 & 40.44 \\
& $30-45$ & 29.33 & 20.37 & 25.00 & 31.59 \\
\hline B & $0-15$ & 16.49 & 90.90 & 21.05 & 28.47 \\
& $15-30$ & 24.48 & 34.48 & 40.98 & 25.50 \\
& $30-45$ & 19.27 & 68.18 & 21.05 & 32.76 \\
\hline C & $0-15$ & 20.00 & 0.00 & 26.32 & 26.17 \\
& $15-30$ & 20.09 & 73.68 & 62.07 & 37.94 \\
& $30-45$ & 26.70 & 60.61 & 22.48 & 30.54 \\
\hline D & $0-15$ & 27.54 & 53.00 & 80.76 & 32.62 \\
& $15-30$ & 29.13 & 63.27 & 37.01 & 35.90 \\
& $30-45$ & 23.33 & 63.27 & 28.29 & 31.35 \\
\hline E & $0-15$ & 32.13 & 37.18 & 24.54 & 60.43 \\
& $15-30$ & 24.90 & 28.00 & 15.83 & 41.51 \\
& $30-45$ & 19.25 & 34.57 & 20.29 & 40.89 \\
\hline F & $0-15$ & 23.25 & 74.07 & 42.42 & 33.33 \\
& $15-30$ & 18.41 & 62.50 & 18.63 & 34.64 \\
& $30-45$ & 25.81 & 66.67 & 22.30 & 33.58 \\
\hline
\end{tabular}

High mobility factor values were observed for cobalt at some soil depths in sites B, C, D and F and for nickel at site $C(15-30 \mathrm{~cm}$ depth) and $\mathrm{D}(0-15 \mathrm{~cm}$ depth). The mobility factor (MF) values of the metals in all the sites and profiles follow the order $\mathrm{Co}>\mathrm{Ni}>$ $\mathrm{Mn}>\mathrm{Fe}$. These values do not follow any particular trend with respect to soil depth. Similar observation was reported by Osakwe and Egharevba (2008). The relatively high mobility factor observed for cobalt is quite in agreement with the high percentage of exchangeable fraction of cobalt recorded from the chemical fractionation results.

Conclusion: The chemical fractionation of the metals 
studied revealed the geochemical nature of the four heavy metals and their probable association with different chemical forms in the soils around the automobile waste dumpsites. The results showed that the heavy metal concentrations found in the residual fraction was higher than those observed in any of the preceding extractions except in the case of cobalt where exchangeable fraction predominated and closely followed by residual fraction. The heavy metal fractionation results gave an overall picture that high percentage of the metals were found to be strongly bound to soil matrix i.e. in a form not readily available for introduction into the food chain except cobalt. This overwhelming importance of the residual fraction in this study illustrates clearly the difficulty of distinguishing between background and anomalous levels of heavy metal contamination when only total metal analyses are performed. The elatively high mobility factor observed in cobalt confirms the high liability, and biological availability of cobalt in some of the soils studied. The present study indicates that the metals studied do not pose environmental risks since the total metal concentration of cobalt which showed high liability and biological availability in this study was very low. Consequently the government can be encouraged to reclaim and utilize the sites for agricultural, residential, commercial or industrial purposes.

Acknowledgement: The author is very grateful to Professor Felix Egharevba of Chemistry Department, Ambrose Alli University Ekpoma and Dr. Michael Horsfall Jnr of Pure and Industrial Chemistry Department, University of Port Harcourt, for their interests and professional advice during the course of this study.

\section{REFERENCES}

Abeh, T; Gungshik, J; Adamu, M M (2007). Speciation Studies of trace elements levels in sediments from Zaramagada stream in Jos, Plateau State, Nigeria. J. Chem. Soc. Nig. 32(2) 218-225.

Ademoroti, C M A (1996). Environmental Chemistry and Toxicologgy. Foludex Press Ltd, Ibadan 150-188.

Ahumada, I, Mendoza, J; and Ascar, L (1999). Sequential extraction in soils irrigated with waste water. Commun. Soil Sci. Plant Anal. 30: 1057-1519.

Ajibola, V O; and Ozigis, I (2005). Partitioning of some Heavy Metals in Kaduna street soils. J. Chem.Soc. Nig. 30(1) 62-66.

Allen, S E, Grinshaw, H M, Parkinson, J A; and Quarmby, C (1974). Chemical methods for analyzing ecological materials. Oxford Blackwell Scientific Publications, London. 565.
Alloway, B J (1990). Heavy metals in soils. Blackie and Son Publishers, Glasgow $2^{\text {nd }}$ Edition.

Brooklin, D G (1988). EL-pH diagram for Geochemistry. Springer, Berlin. 176.

Burrell, D C (1974). Atomic spectrometric analysis of heavy metals in water. Ann. Arbor., Michigan 19-32.

Carot, S; O’ Day, P.A; Esser, B; and Randal, S (2002). Speciation and fate of trace metals in estuarine sediments under reduced and oxidized conditions. Seaplane Lagoon. Alameda Naval Air Station (USA). Geochem. Trans. 3(10): 81-101.

Chaudhary, S Benerjee D K (2008). Speciation of some heavy metals in coalfly ash. Chem. Spec..Bio 19(3): 95-102.

Egila, J N; Nimyel, D N (2002). Determination of trace metal speciation in sediments from dams in Plateau State, Nigeria. J. Chem. Soc. Nig. 27(1): 7175 .

Evans, E; Ma, M; Kingston L.; Lecharne, S; and Chowdhry, B (1992) The speciation pattern of lead in street dusts and soils in the vicinity of two London schools. Environ. Inter. 18:153-162.

Graham, D R; Stangoulis, J C (2003). Trace element uptake and distribution in plants. Crit. Rev. Plant Sci. 14: 49-82.

Gupta, S K; Chen, K Y (1975). Partitioning of trace metals in selected chemical fractions of near shore sediments. Environ. Lett. 10: 129-158.

Hakanson, L (1992) Sediment Variability. In: Burton, G.A. Jr. (ed) Sediment Toxicity Assessment. Lewis Publishers, Boca Raton. Fl. 19-36.

Hickey, M G; Kittrick, J A (1984). Chemical partitioning of cadmium, copper, nickel and zinc in soils and sediments containing high levels of heavy metals. J. Environ. Qual. 13: 372-376.

Horsfall, M (Jnr.); and Spiff, A (2005). Speciation and bioavailability of heavy metals in sediment of Diobu River, Port Harcourt, Nigeria. Europ. J. Sci. Res. 6(3): 20-36.

Iwegbue, C M A (2007). Metal fractionation in soil profiles at automobile mechanic waste dumps. Waste Manage. Res. 25: 1-9.

Jenne, E A (1968) Controls of Mn, Fe, Co, Ni, $\mathrm{Cu}$ and $\mathrm{Zn}$ concentrations in soils and water. The significant role of hydrous $\mathrm{Mn}$ and Fe oxides, In: 
Traceinorganics in water Gould, R.F. (ed) Advances in Chemistry Series, N. 73 Ame. Chem. Soc. Washington D.C. 337-387.

Kabala, C; Singh, B R (2001). Fractionation and Mobility of Copper, lead, and zinc in Soil Profile in the vicinity of a Copper Smelter, J. Environ. Qual. 30:485-495

Karczewska, A (1996). Metal species distribution on top and subsoil on an area affected by smelter emission. Appl. Geochem. 11: 35-42.

Kestern, M; Forstner, U (1989). Speciation of trace elements in sediments In: Batley, G. (ed). Trace Element Speciation. Analytical Methods and Problems. CRC Press, Boca Raton, FL. 245.

Kotoky, P; Bora, B J; Baruah, N K; Baruah, J; Baruah, P and Borah, G C (2003). Chemical fractionation of heavy metals in soils around oil installation, Assam. Chem. Spec. Bio. 15(4): 115125.

Ma, L Q and Rao, N (1997). Chemical fractionation of cadmium, copper, nickel and zinc in contaminated soils. J. Environ. Qual. 26: 259-264.

McBride, M B (1997). Environmental Chemistry of Soils. Oxford University Press, New York. 406.

Narwal, R P; Singh, B R; Selbu, B (1999). Association of Cadmium, Zinc, Copper. And Nickel with Components in Naturally Heavy Metal Rich Soils Studied by Parallel and Sequential Extraction. Commun. Soil Sci. Plant Anal., 30, 1209 - 1230.

Norrish, K (1975). Geochemistry and mineralogy of trace elements. In: Nicholas, D.J.D. and Egan, A.R. (eds). Trace elements in soil-plantanimal systems. Academic Press, Inc. New York.

Osakwe, S. A. and Egharevba, F. (2008). Sequential Fractionation of cadmium, copper, lead and chromium, in soil around, Municipal Solid Waste Dumps in Agbor, Nigeria. J. Chem. Soc. Nig. 33, (2) $; 139-147$

Pizzaro, J; Rubio, M Castillo, X (2003). Study of chemical speciation on sediments. An approach to vertical metal distribution in Rapel reservoir (Chile) J. Clil. Chem. Soc. 48: 45-50.

Ramos, L; Hermandez, L M; Gonzales, M J (1994). Sequential fractionation of copper, lead, cadmium and zinc in soils from Danana National Park. J. Environ. Qual. 25: 50-57.

Reedy, K R; Xu, C Y; Chinthamreddy, S (2001). Assessment of electrokinetic removal of heavy metals from soils by sequential extraction analysis. J. Haz. Mat. B. 84: 279-296.

Ryan, PC; Wall, A J; Hiller, S; Clarke, L (2002). Insight into sequential chemical extraction procedure from quantitative XRD: a study of trace metal partitioning in sediments related to frog malformities. Chem. Geol. 184: 337-357.

Sakata, M (1983). Simple and Rapid Methods for the Determination of Ten Heavy Metals in Sediments. Central Research Institute of Electric Power Industry Report, E2, 83001.

Salbu, B; Kreling, T; Oughton, D H (1998). Characterization of Radioactive Particles in the Environ. Anal. 123: 843-849.

Schwarzenbach, R P; Gschwend, P M Imboden, D.M. (1993). Environ. Org. Chem. John Wiley and Sons, Inc., New York. 259-261.

Segarra, M J B; Prego, R.; Wilson, M J; Bacon, J and Santos-Echeandia, J S (2008). Metal speciation in surface sediments of the Vigo Ria (N.W. Iberian Peninsula) Sci. Mar. 72(1): 119-126.

Stumn, W and Morgan, J J (1981). Aquatic Chemistry; Chemical Equilibra and Rates in Natural Water. John Wiley and Sons Inc. USA. 1022.

Tessier, A; Campbell, P G C (1980). Trace metal speciation in the Yamaska and St. Francis River (Quebec). Can. J. Earth Sci. 17: 90-105.

Tessier, A; Campbell, $\mathrm{P}$ G C; Bisson, $\mathrm{M}$ (1979). Sequential extraction procedure for the separation of particulate trace metals. Anal Chem 51: 844-851.

Urunmatsoma, S O; Ikhuoria, E U (2005). Effect of leachates (heavy metal content) from solid waste at "Effurun roundabout dumpsite" Warri, Nigeria. Chem.. Tech. J. 1: 195-202.

Zhang, T; Shan, X. and Fuliang, L (1998). Comparison of two sequential extraction procedures for speciation analysis of metals in soils and plant availability. Commun Soil Sci. Plant Anal. 29(7 and 8): 1023-1034. 